\title{
TRANSFORMATION OF THE ROLE OF STATE IN ECONOMY IN GLOBALIZATION CONDITIONS
}

\section{Koliada Tetiana ${ }^{1}$ Muzychenko Ganna ${ }^{2}$}

DOI: https://doi.org/10.30525/978-9934-571-89-3_131

The financial crisis of 2008-2009 has demonstrated the lack of theoretical research on the state as a public goods and services producer and on the optimal scale of state intervention to the institutional structure of the national economic system as well.

The dominant scientific paradigm of the interpretation of the essence of the interaction of the state and the market, based on neoclassical approaches and views of other economical schools' representatives according to which the state is devoted to increase the level of market efficiency by eliminating its "failures", proved to be imperfect due to the inability to explain modern institutional transformations [1, p. 421].

The globalization processes' strengthening has substantially changed the understanding of the public finances essence and led to the evolution of theoretical approaches to their interpretation. The traditional public finance theory based on the welfare and public choice focuses on the formation of the revenue and expenditure part of the central (state) and local budgets, examines the mechanism of their interaction in the context of financing public goods and services. A new theory of public finance considers the interaction of the state and the market in the context of cooperation and competition between public and private market agents regarding the provision of public services and takes into account the need for concerted action of governments at the national and international levels to address global development challenges, especially in the face of aggravation of the crisis phenomena in the economy.

\footnotetext{
${ }^{1}$ University of State Fiscal Service of Ukraine, Ukraine

${ }^{2}$ South Ukrainian National Pedagogical University named after K.D. Ushynsky, Ukraine 
Under conditions of globalization, when the economy goes beyond the bounds of the state, the problem of interdependence between the state and the economy becomes of particular importance for economic methodology. Economic determinism' followers associate this process with the dismantling of state institutions in general, with the self-liquidation of the state as such. Instead, A. S. Galchinsky believes that this problem is associated with a profound systemic reconstruction of state functions, which are due to the controversial process of becoming a post-industrial, global society [2, p. 471].

We are agree with Galchinsky's opinion that the modern global information economy, which operates on-line, is based on a fundamentally different basis. A new understanding of the need for a systemic separation of political power and economy is going to change the previous Keynesian and Neo-Keynesian approaches based on the state's functions expansion. It is about the limiting of state's economic function and developing new mechanisms for economy regulation, which will be formed within the economy itself.

Global economy changes have forced the scientific community to return to basic questions about the state: what should be its role, task, function, because the sustainable development - both economic and social - is impossible without an effective state. The lack of an adequate theoretical basis for interpreting the state's role and its functions in national economies negatively affected the prospects of exit from the structural and financial crisis [1, p. 422].

In the current multifaceted, mixed market economy, the state plays an active role in shaping the most important processes of socio-economic development. The public sector has a dominant position in the economy due to using resources to finance stateguaranteed public services and various income redistribution programs. The public sector also plays an important role in the financial markets of most countries, owing to significant amounts of its borrowing from the private sector and a substantial amount of its assets in the economy. The public services financing and the income redistribution in most countries of the Organization for Economic Cooperation and Development (OECD) exceeds $40 \%$ of GDP, and in some countries it even approaches $50 \%$ of GDP [1, p. 430]. The state's influence magnitude is particularly increasing in the period of aggravation of the economic and social situation in the country. In periods of stable development and absence of crises, the scale of government influence is shrinking and the state, like other market agents, operates within defined long-term programs and strategies.

The growth of the state's role in the income redistribution is inherent in all European countries. Their common feature is a significant share of public expenditure in GDP. It can be argued that in most countries with a developed market economy, the indicators characterizing the budgetary burden are comparable. Due to the integration of economic, financial, currency, and credit systems in European countries, the convergence process has taken place - equalizing the value of financial and budgetary indicators, in particular, the budget deficit, public debt, inflation, interest rates, etc. Among the main benefits of such integration is the coordinated, even development of all EU Member States. The disadvantage of such an association 
is the particular country government inability to accelerate its own economy development.

In order to compare the EU countries and Ukraine budget structure indicators correctly, the amount of deductions to extrabudgetary funds (pension and social), which were also reflected in the social benefits indicator, was added to the Ukrainian budget expenditures (Table 1).

Table 1

Budget burden in EU-28 countries and Ukraine, \% of GDP

\begin{tabular}{|l|c|c|c|c|c|c|c|c|}
\hline \multicolumn{1}{|c|}{ Indicators } & $\mathbf{2 0 1 0}$ & $\mathbf{2 0 1 1}$ & $\mathbf{2 0 1 2}$ & $\mathbf{2 0 1 3}$ & $\mathbf{2 0 1 4}$ & $\mathbf{2 0 1 5}$ & $\mathbf{2 0 1 6}$ & $\mathbf{2 0 1 7}$ \\
\hline EU-28 countries & 50,0 & 48,6 & 49,0 & 48,6 & 48,2 & 47,4 & 47,2 & 46,9 \\
\hline Ukraine & 45,9 & 42,7 & 46,1 & 46,3 & 44,6 & 45,0 & 45,8 & 45,2 \\
\hline
\end{tabular}

Source: compiled according to the statistics of the European Union (http://appsso.eurostat.ec.europa.eu) and the State Statistics Service of Ukraine (http://www.Ukrstat.org)

According to the data, the budgetary burden in Ukraine is slightly lower than in the EU zone's countries, but the domestic indicator is characterized by considerable volatility and the opposite trend direction for its changes. If in European countries there is a tendency to decrease or stabilize the growth rates of budget expenditures, in Ukraine, their uneven gradual growth occurs.

Before consolidating the budget and looking for mechanisms for its implementation, it is necessary to clearly determine at the state level what the demand or supply economy the government is trying to build in the country, since it will depend on the choice of directions and volumes of budget funds spending.

The all leading countries' governments have faced with the impossibility of constantly stimulating demand in the context of the global economic recession. Due to restrictions on public investment, falling living standards, reducing the private investment volume and the unavailability of credit resources, the proposals to return production to the metropolis are increasingly being heard as one of the options for anti-crisis maneuver of states, which can reduce unemployment and create new jobs.

There is a question for the world about the transition to a new model for building economic relations - the economy of the proposal, which involves modernization as a basis - production, and its superstructure - the nature of public relations. And the fiscal policy forms and reflects the type of state economic model.

The state must concentrate its limited resources on clearly defined basic functions. Budget policy should be based on the relative state participation effectiveness assessment in various economic activity's spheres and minimize the budgetary resources distribution in areas where the state's participation is unnecessary or ineffective.

In the context of the globalization and the transparency of most economies in the world, when crises are of an all-embracing nature, and among the factors that trigger them the institutional ones become dominate, we must talk about the decisive role of the state in overcoming the crisis phenomena, the need for intervention in market mechanisms and the introduction of manual control of the situation. At the same time, 
it should be emphasized that the modern socio-economic structure of Ukraine, which was formed as the economy institutional transformation result, is characterized by the strengthening of the state's role as a public goods producer, as is the case for most European countries.

In the context of fiscal consolidation and post-crisis economic recession, it is imperative to reduce the social benefits list and state support directions. At the same time, the social benefits' total amount received by one person per month can not be higher than the subsistence minimum. It is necessary to legislatively fix restrictions on the maximum for the social assistance's amount per person. It is also necessary to determine clearly which categories of citizens need state social assistance and on what criteria such categories of population will be determined [3, p. 331].

It is necessary to return to the ideology that a person should work to keep himself and his family safe if he has no restrictions on his health or for other reasons. The state is not obliged to give money to citizens, but only to create conditions for obtaining work. Therefore, the priority task is to prepare public opinion for the transition to a new model of relations with the state. Such an initiative should come not only from the state, it is necessary to involve public organizations and scientists to explain the irreversibility and the need for such transformations, to highlight the benefits that citizens of most democratic and market-rich countries of the world already have.

\section{References:}

1. Koliada T., Muzychenko G. (2018). Evaluation of the State Intervention to the Country Economy by Global Democratic Markers. Scientific Development and Achievements. London: Sciemcee Publishing London, vol. 1, pp. 421-433.

2. Galchinsky A.S. (2010). Ekonomichna metodologiya. Logika onovlennya: Kurs lekcij [Economic methodology. Logic Upgrade: Lecture Course], Kyiv: ADEF-Ukraine, 572 p. (in Ukrainian)

3. Muzychenko G., Koliada T., Churkina I. (2017). Impact of European integration processes on the necessity of long-term budget planning introduction in Ukraine. Baltic Journal of Economic Studies, vol. 3, no. 5, pp. 329-333. doi: 10.30525/2256-0742/2017-3-5-329-333 